HOW, a Colombian Journal of Teachers of English. No. 4. (pp. 19-24). (ISSN: 0120-5927). 1998.

APA citation style: Benavides B., Jorge E. (1998). Integrating CALL into the Language Curriculum. HOW, a Colombian Journal of Teachers of English) (4), 19-24.

\title{
Integrating CALL into the Language Curriculum
}

\author{
Jorge E. Benavides B. (joelbebu@gmail.com) \\ Department of Linguistics and Languages \\ Universidad de Nariño, San Juan de Pasto, Colombia
}

\begin{abstract}
This initial proposal aims at suggesting one way in which Information Technology in the form of CALL (Computer-Assisted Language Learning) could be integrated into the foreign language curriculum of the licenciatura programs in Colombia. This task can be carried out as the project within the different universities in order to support and improve the learning and teaching of English which is one of its main objectives.
\end{abstract}

\section{CALL in the language curriculum}

At international level we know that many English programs -as well as native language programs- have introduced some form of CALL in their curricula. This implies that there has to be some kind of organization, planning and structure of this new academic element. Planning, course design, materials design, testing, evaluation, assessing as well as a good dose of knowledge in computers has to be taken into account for this type of implementation.

There is a world-wide trend to initiate the first steps into what is called technologically-based aids to learning, and therefore we can suggest a pedagogically oriented CALL, that is, a variety of innovative language-learning activities. We can get to know new tools and new environments for learning, and consequently new language learning strategies. This has to lead to changes in terms of learner independence, since CALL can start as part of classroom work. Then CALL could be well found in language learning centers or resource centers. Within CALL we can also combine teaching with research on learning in this new field keeping track of what learners do in order to get to know more about the learning process.

We need to understand first of all the ways in which technology-based materials, facilitate language learning. And this is a task that might be undertaken by teachers, administrators, and students since most of the reports on CALL are basically anecdotal and do not have an empirical basis. There is a wide range of interdisciplinary research in this area and we can take advantage of the research experiences on second and foreign language acquisition and learning in the 60's and 70's in order to make a more consistent and profitable work.

\section{CALL in the Colombian foreign language programs}

An important area that deserves especial attention comes from the new Colombian Constitution. It contemplates that every member of society has the right to access information and therefore the right to access education. However, education and therefore some forms of 
accessing information have somehow been changed by the information revolution in terms of how it is handled and used. We are probably facing in education something similar to what happened during the industrial revolution where the means of production and the concept of the very production were changed.

In Colombia there are some institutions of higher education that have initiated some sort of introduction to "computers in language teaching and learning" with their new language programs. This is not only true for the language programs but also for most of the careers and specialization at undergraduate and graduate levels in the country. However, most of the programs consider this introduction as a part of the knowledge that future professionals have to have in order to deal with their future computerized activities. For the sake of language teaching and learning the use of computers have to serve a different purpose: a pedagogical and learning-based platform. Some of the reasons and justification for setting up a CALL-based component in the language programs are the following, among others.

In the first place, the technological requirements are already available. Almost every university in Colombia has a computer room which can be used as a first instance to apply CALL in an introductory stage. However, the language departments in each institution in the near future will have to consider the implementation of a computer laboratory, a specifically designed room as a self-access center where learners will have to cope with the technologically-based pedagogy as stated by Benavides, (1997).

Second, the government and its new policies of openness and change in education will have to facilitate the introduction of this type of Educational technology, not only for the language programs but also for the majority, if not all, of the basic areas in education.

Third, learners seem to be enthusiastic (according to our recent experience using CALL materials: their reactions and performance) about the possibility of using computers to satisfy their learning needs and interests. Computer-aided activities have been beneficial in order to facilitate the first contact with the computer, and programs are, contrary to widely held beliefs, not at all limited to drill and practice methodology but can be fitted into a communicative approach to language learning.

Four, there is a wide range of materials productivity in the realm of CALL. Teachers and students will have to learn at least an authoring language, if not a programming language, in order, to develop materials for their students. Not all what is commercially produced is pedagogically sound for applying to language teaching and learning. Therefore, future teachers will have to become proficient in handling a computer language.

\section{CALL, Self-Access, and Autonomous Learning}

As proposed by McDonough, (1993) and exemplified by Stoller, (1984), (cited in Mcdonough, 1993) one of the ways of enriching and supporting the language curriculum and promoting independent learning is through the appropriate use of Information technology represented in 
CALL as in or out of classroom activities. However, it is important to consider that technologybased learning, whether it is integrated into the language curriculum or used as a self-access system is not to be taken as a panacea or even worse as a complete substitution of classroom instruction. It has to start as supplementary work of what is done in the classroom, and this is especially considered during the first stages of CALL introduction into the language curriculum.

The concerns and questions to be asked before thinking of introducing new technology in the language curriculum are, among others:

- How and to what extent can Information technology be introduced into the language curriculum?

- To what extent can it be introduced to support educational goals?

- What is the most appropriate technology?

- How is the new technology going to be used?

- How effective is it for language learning?

\section{Appropriate technology and effective learning}

Another area of concern not only for teachers but for curriculum developers, course designers and course evaluators is the effectiveness of CALL. So we can start asking ourselves How and to what extent can IT in the form of CALL contribute to enriching the language curriculum and therefore enhancing and improving language learning? The answer to this question will have to be dealt in the process, before, and after the introduction of CALL.

In general terms, we can say that an appropriate integration of CALL into the language curriculum would be able to achieve the following goals:

- $\quad$ Provide the means for achieving some degree of computer literacy for teachers and students.

- $\quad$ Familiarize teachers and students with the demands of IT in language learning as part of the education scheme.

- $\quad$ Give confidence to teachers and students to the use of computers for language learning.

- $\quad$ Provide teachers with different modes for language teaching.

- $\quad$ Provide students with different modes for language learning.

- $\quad$ Provide teachers with the context for doing research in language learning in CALL.

\section{Justification}

Much of the justification for introducing new technology in the language curriculum comes from the relative success other areas in education have experienced in using it. Other curricula like math, engineering, physics, etc. have included the use of computers as part of the teachers and students work. Also, in other areas at university level, computers have been used for demonstrations, presentations and workshops as classroom work for instructional purposes. 
Furthermore, we can find that in other fields of human activity, like business, and administration, computers have widely and progressively been used.

But most importantly, the demands of using computers for educational purposes come from pressure from the very society at large. It is by no means unknown that many people whether at work or at home, for educational of professional reasons use computers to some degree. Children, teenagers and young adults are familiarizing and integrating their work with computer use at home and therefore getting acquainted with some form of computer literacy.

Therefore, computers are involved as the information technology field in almost every aspect of human activity included education. Thus the availability of the technology in education means that one of its subsets, that is, the language curriculum will have to include computers as a support in language teaching and learning, that is, CALL.

\section{Objectives}

The main objective of this process will be to support and improve language learning and language teaching in the language curriculum. Other, more specific objectives are:

- To introduce the component of Computer-Assisted language learning in our language programs and make courseware available for teachers and students.

- $\quad$ To develop a more autonomous learning initiative with CALL as a supplement of classroom work and towards self-access learning.

- $\quad$ To prepare the future language teachers into appropriate use of ICT and CALL.

- $\quad$ To evaluate the use of CALL and its materials.

- $\quad$ To do research as the basis for pedagogical practice of CALL.

\section{Conditions for CALL integration into the language curriculum}

In order to achieve the above-mentioned goals for the successful implementation of CALL there some conditions that must be fulfilled.

- Resources:

In order to achieve educational goals in IT, there must be a minimum of resources available. These include physical facilities as well as the hardware (computers) and the software (computer programs).

\section{- Training:}

Teacher training is a key factor in approaching a successful CALL implementation into the language curriculum. As we have seen throughout this document, teachers are the first to be acquainted with the good use of Information Technology for their learners to learn from them.

\section{- $\quad$ Funding}

Funds are necessary not only to implement the resource centers (hardware, software and materials acquisition) but also to promote materials production and research in the near future. 
The 'Secretarías de Educación', ICFES, ICETEX, and the Colombian Universities involved could fund the initial implementation. This could be done to enrich the new Resource Centers created by the COFE project.

\section{Stages within the CALL project}

This project intended to introduce CALL in the Colombian language programs can be proposed in three steps: the introductory stage, the operational stage and integrational stage.

\subsection{The introductory stage}

Before introducing CALL in the language programs, not only for pedagogical purposes but also for empirical research, we need to convince our colleagues of the importance of considering CALL as an alternative form of language learning and autonomous learning. This can be done by means of conferences, seminars, workshops, and demonstrations. Teachers and administrators are to be the first in getting to know about CALL. Furthermore, we need to contact more people interested in this area by means of a periodical publication which will serve of channel of communication among teachers.

\subsection{The operational stage}

This stage will start once teachers and administrators at their institutions are aware of the need to explore the potentiality of computers for language learning. The fact that there will be no dogma that says 'CALL has to be done in only one way' can open up the possibility for some systematic attempts at exploring CALL in our system.

\section{Objectives of this stage}

- $\quad$ To enhance the pedagogical strategies used by the teacher.

- To develop new learning strategies.

- $\quad$ To serve as a point of reflection in terms of the way we want our system to change using technology appropriately.

- $\quad$ To do exploratory research in foreign language learning.

- To form links with other institutions, reporting on weaknesses and strengths of the process.

\subsection{The integrating stage}

This stage will arrive when all aspects of CALL are put in practice within the curricula and the language programs, and a unified and systematic approach of implementation of CALL can be

obtained. At this stage the first attempts at doing research will be consolidated. Research and experimentation will be the basis for enriching the pedagogical field of CALL.

- Working bases

The project can be centralized having each base located in each University which will be involved in the project and which will report to a center base. 


\section{- Resources centers}

Each base at each university will have a resource center, where computers, software, and personnel will be available for working and directing the CALL component. These resources centers will have two functions:

- $\quad$ As teacher training bases in the use of computers for language learning.

- As a medium of transformation of the members of the community interested in CALL activities.

\subsection{The project's committee}

Since there has to be some kind of organizational structure, the project could be operated by a committee which will be in charge of starting the work at each institution or base, that is, at each university (language department, faculty of education, language school etc.) Some of the tasks of this committee are, among others:

- $\quad$ Collect and compile information about CALL

- $\quad$ Provide technical expertise on aspects related to CALL

- $\quad$ Schedule seminars, conferences, workshops and demonstrations about CALL

- Inform the community about the progress of the project by means of a periodical publication (i.e. CALL newsletter)

- $\quad$ Get informed about possible acquisition of CALL resources

- $\quad$ Collect and organize reference books, articles, periodicals software and guides for information.

\section{Conclusion}

There is always a danger when considering the introduction of new technologies in education. Here, a real danger is that speed and apparent inevitability of the technological invasion will persuade teachers that they no longer have a stake in decision making about language learning innovation. This is however far from accurate. It can be argued with considerable strength, that teachers must continue to see their role as that of shaping and directing both the pace and the direction of the introduction of computers in the classroom and off the classroom as self-access work and this involves a lot of systematic reflection, being open to innovation, but constructively critical of it.

\section{References}

Benavides, B., Jorge E. (1997). The Educational Context of Computer-Assisted Language Learning. HOW, a Colombian Journal of Teachers of English) (2), 57-60.

McDonough, J. \& Shaw, C. (1993). Materials and Methods in ELT: A teachers Guide. Cambridge, Massachusetts: Blackwell.

Stoller, A. (1984). Freedom to learn. Columbus, OH: Chas. E. Merrill Publishing Co. 